\title{
Structural, Spectroscopic, Thermal, and Magnetic Properties of a New Dinuclear Copper Coordination Compound with Tiglic Acid
}

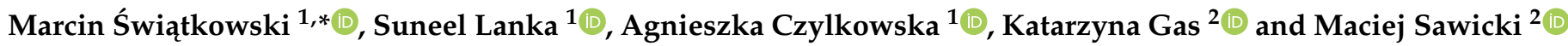 \\ 1 Institute of General and Ecological Chemistry, Lodz University of Technology, Zeromskiego 116, \\ PL-90924 Lodz, Poland; suneel.lanka@dokt.p.lodz.pl (S.L.); agnieszka.czylkowska@p.lodz.pl (A.C.) \\ 2 Institute of Physics, Polish Academy of Sciences, Aleja Lotnikow 32/46, PL-02668 Warsaw, Poland; \\ kgas@ifpan.edu.pl (K.G.); mikes@ifpan.edu.pl (M.S.) \\ * Correspondence: marcin.swiatkowski@p.lodz.pl
}

check for updates

Citation: Świątkowski, M.; Lanka, S. Czylkowska, A.; Gas, K.; Sawicki, M. Structural, Spectroscopic, Thermal, and Magnetic Properties of a New Dinuclear Copper Coordination Compound with Tiglic Acid. Materials 2021, 14, 2148. https:// doi.org/10.3390/ma14092148

Academic Editor: Anastasios J. Tasiopoulos

Received: 26 February 2021

Accepted: 21 April 2021

Published: 23 April 2021

Publisher's Note: MDPI stays neutral with regard to jurisdictional claims in published maps and institutional affiliations.

Copyright: (c) 2021 by the authors. Licensee MDPI, Basel, Switzerland. This article is an open access article distributed under the terms and conditions of the Creative Commons Attribution (CC BY) license (https:// creativecommons.org/licenses/by/ $4.0 /)$.

\begin{abstract}
The first coordination compound of copper and tiglic acid named tetrakis( $\mu$-tiglato)bis(tiglic acid)dicopper(II) was synthesized and crystallized from water solution. Its structure was determined and analyzed based on X-ray diffraction measurement. The paddle-wheel coordination system of the investigated compound was compared with other similar copper structures known in the literature. The Hirshfeld analysis was used for the detailed analysis of intermolecular interaction. The new compound was also characterized in terms of infrared absorption, thermal, and magnetic properties. The antiferromagnetic coupling of copper ions was found.
\end{abstract}

Keywords: coordination compound; copper; tiglic acid; crystal structure; IR spectroscopy; thermal analysis; magnetic properties

\section{Introduction}

More commonly known as tiglic acid, (2E)-2-Methylbut-2-enoic acid is one of the simplest unsaturated monocarboxylic acids (Figure 1). It is a volatile, crystalline solid with a distinctive, sweet odor. Tiglic acid naturally occurs in croton oil. It can also be found in the secretions of certain species of beetles [1,2]. Along with angelic acid, it forms a pair of cis-trans isomers.<smiles>CC=C(C)C(=O)O</smiles>

Figure 1. The chemical formula of tiglic acid.

Unsaturated organic acids are important compounds considering their industry applications. Their esters are widely used in the food, cosmetic, and pharmaceutical industries [3]. Tiglic acid is not an exception-along with its derivatives, it is an important flavoring agent and fragrance additive. Tiglic acid can be used in the processes of manufacturing rum, caramel, bread, and fruit essences [4]. Its derivatives also exhibit potential anti-inflammatory [5] and antiproliferative activity [6]. One of the biggest areas of interest concerning tiglic acid is its biosynthesis-naturally occurring flavors and fragrances synthesized using enzymes can be labeled as "natural" [3,7]. The coordination chemistry of tiglic acid has not been widely explored to date [8-11]. In the Cambridge Structural Database (CSD) [12], there are only 15 compounds whose structures contain such acid or 
its anion; thus, every new research effort in this field provides important knowledge and fills the existing literature gap.

The carboxylic acids exhibit a tendency to form dinuclear coordination compounds with copper. Such compounds possess the paddle-wheel structure in which two copper cations are bridged by four carboxylate anions. Most often, the paddle-wheel structure is completed by two terminal axial ligands. Research on dinuclear copper compounds has been conducted since the 1950s [13-15], and they are still of great interest due to i.a. magnetic properties [16-22]. The spin exchange parameter (-2 J) for such compounds is most often in the range $200-600 \mathrm{~cm}^{-1}$, which means antiferromagnetic coupling [23-25]. The value of this parameter is not only dependent on $\mathrm{Cu} \bullet \bullet \bullet \mathrm{Cu}$ distance but also on other structural parameters, e.g., lengths of $\mathrm{Cu}-\mathrm{L}$ (axial) bonds, lengths of $\mathrm{Cu}-\mathrm{O}-\mathrm{C}-\mathrm{O}-\mathrm{Cu}$ bridges, $\mathrm{O}-\mathrm{Cu}-\mathrm{O}$, and $\mathrm{Cu}-\mathrm{Cu}-\mathrm{O}$ angles as well as on the electronic properties of ligands [23-25].

This work presents the synthesis, crystal structure, and study of spectroscopic, thermal, and magnetic properties of the new coordination compound of copper and tiglic acid tetrakis( $\mu$-tiglato)bis(tiglic acid)dicopper(II).

\section{Materials and Methods}

\subsection{Synthesis of $\left[\mathrm{Cu}_{2}(\mathrm{tig})_{4}(\mathrm{tigH})_{2}\right]$}

Copper(II) carbonate hydroxide (15.9 g, 0.0721 mol, POCh, Gliwice, Poland) and tiglic acid (28.0 g, 0.2800 mol, Sigma-Aldrich, Darmstadt, Germany) were placed in a round-bottom flask with $250 \mathrm{~cm}^{3}$ of water. The reaction mixture was heated under a reflux condenser for $6 \mathrm{~h}$. Then, the unreacted copper(II) carbonate hydroxide was filtered off and the clear solution was left to crystallization at room temperature. Green single crystals of $\left[\mathrm{Cu}_{2}(\mathrm{tig})_{4}(\mathrm{tigH})_{2}\right]$ were obtained after several weeks. They were filtered and dried in the air. The yield of the synthesis calculated in relation to tiglic acid (substrate used in deficiency) was $56 \%$ (resulting mass $18.9 \mathrm{~g}$ ).

\subsection{Crystal Structure Determination}

X-ray diffraction data of $\left[\mathrm{Cu}_{2}(\mathrm{tig})_{4}(\mathrm{tigH})_{2}\right]$ were collected on a Rigaku Synergy Dualflex automatic diffractometer (Rigaku Corporation, Tokyo, Japan) equipped with Pilatus $300 \mathrm{~K}$ detector and microfocus sealed PhotonJet X-ray tubes, with shutterless $\omega$ scan mode. Lorentz, polarization, and empirical absorption (using spherical harmonics, implemented in SCALE3 ABSPACK scaling algorithm) corrections were applied during the data reduction. The structure was solved with a dual-space algorithm (SHELXT [26]). All nonhydrogen atoms were refined anisotropically using a full-matrix, least-squares technique on $F^{2}$ (SHELXL [27]). All hydrogen atoms were refined using the "riding" model. Isotropic displacement factors of hydrogen atoms were equal to 1.2 times the value of an equivalent displacement factor of parent methine carbon atoms, and 1.5 times of parent hydroxyl oxygen and methyl carbon atoms. Structural visualizations were made in Mercury CSD 4.3.0 (Cambridge Crystallography Data Centre, Cambridge, UK) [28]. Hirshfeld surface maps and the fingerprint plots were generated using Crystal Explorer 17.5 (University of Western Australia, Nedlands 6009, Australia) [29] Details concerning crystal data and refinement are given in Table 1.

CCDC 2045148 contains the supplementary crystallographic data for this paper. These data can be obtained free of charge via http://www.ccdc.cam.ac.uk/conts/retrieving.html (or from the CCDC, 12 Union Road, Cambridge CB2 1EZ, UK; Fax: +44-1223-336033; E-mail: deposit@ccdc.cam.ac.uk). 
Table 1. Crystal data and structure refinement details for $\left[\mathrm{Cu}_{2}(\mathrm{tig})_{4}(\mathrm{tigH})_{2}\right]$.

\begin{tabular}{|c|c|}
\hline Empirical formula & $\mathrm{C}_{30} \mathrm{H}_{44} \mathrm{Cu}_{2} \mathrm{O}_{12}$ \\
\hline Formula weight & 723.73 \\
\hline Crystal system & Monoclinic \\
\hline Space group & $P 2_{1} / c$ (No. 14$)$ \\
\hline Temperature (K) & $100.0(1)$ \\
\hline X-ray wavelength $(\AA)$ & $\lambda(\mathrm{CuK \alpha}) 1.54184$ \\
\hline \multicolumn{2}{|l|}{ Unit cell dimensions } \\
\hline $\mathrm{a}(\AA)$ & $9.2533(1)$ \\
\hline $\mathrm{b}(\AA)$ & $17.4061(1)$ \\
\hline$c(\AA)$ & $10.2739(1)$ \\
\hline$\alpha\left({ }^{\circ}\right)$ & 90 \\
\hline$\beta\left(^{\circ}\right)$ & $95.113(1)$ \\
\hline$\gamma\left({ }^{\circ}\right)$ & 90 \\
\hline Volume $\left(\AA^{3}\right)$ & $1648.17(3)$ \\
\hline $\mathrm{Z}$ & 2 \\
\hline Calculated density $\left(\mathrm{Mg} / \mathrm{m}^{3}\right)$ & 1.458 \\
\hline Absorption coefficient $\left(\mathrm{mm}^{-1}\right)$ & 2.101 \\
\hline$F(000)$ & 756 \\
\hline Crystal size (mm) & $0.078 \times 0.093 \times 0.098$ \\
\hline$\theta$ Range for data collection $\left({ }^{\circ}\right)$ & 4.798 to 78.728 \\
\hline Index ranges & $-11 \leq \mathrm{h} \leq 11,-21 \leq \mathrm{k} \leq 21,-13 \leq 1 \leq 12$ \\
\hline Reflections collected/unique & $33781 / 3438$ \\
\hline $\mathrm{R}_{i n t}$ & 0.0252 \\
\hline Completeness (\%) & $100.0\left(\right.$ to $\left.\theta=67^{\circ}\right)$ \\
\hline Min. and max. transmission & 0.50235 and 1.00000 \\
\hline Data/restraints/parameters & $3438 / 0 / 206$ \\
\hline Goodness-of-fit on $F^{2}$ & 1.059 \\
\hline Final $R$ indices $[I>2 \sigma(I)]$ & $\begin{array}{r}R 1=0.0247 \\
w R 2=0.0663\end{array}$ \\
\hline R indices (all data) & $\begin{array}{l}R 1=0.0252 \\
w R 2=0.0666\end{array}$ \\
\hline Largest diff. peak and hole $\left(\mathrm{e} \bullet \AA^{-3}\right)$ & 0.345 and -0.359 \\
\hline
\end{tabular}

\subsection{Magnetic Measurements}

Magnetic studies were performed in a commercial superconducting quantum interference device (SQUID) magnetometer MPMS XL5 of Quantum Design. To facilitate adequately sensitive SQUID measurements of powdered substances, gelatin capsules or other unreliable containers were not used. Instead, the powder material was stabilized with a strongly ethanol-diluted GE-varnish [30]. GE is a well-known low temperature bonding agent particularly handy for such studies as it introduces a marginally weak magnetic flux. Subsequently, the wet mixture was transferred onto a $5 \times 4 \times 0.15 \mathrm{~mm}^{3}$ piece of previously well magnetically characterized silicon (Si). The Si plate provides a solid support and eases the handling of the specimen. After evaporation of ethanol, the GE-stabilized powder and the Si plate form a robust structure, which survived perfectly intact the mounting in the magnetometer and the whole magnetic $H$ field and temperature $T$ cycling applied during the measurements. The relatively weak magnetic signal of the $\mathrm{Si}$ base plate was adequately removed from the results, yielding the magnetic response of the investigated $\left[\mathrm{Cu}_{2}(\mathrm{tig})_{4}(\mathrm{tigH})_{2}\right]$. For the measurements, the whole structure was affixed at the center of about a $20 \mathrm{~cm}$ long silicon strip using the same dilute GE varnish. The Si strip takes the role of the sample holder assuring the adequate sample position with respect to the SQUID pick-up coils, without introducing any detectable signal. All the measurements, data reduction, and final magnetic moment determination were performed following strictly the already described procedures adequate for high sensitivity studies of a sample of minute magnetic signals [31]. 


\subsection{Other Measurements}

The elemental analysis of $\mathrm{C}, \mathrm{H}$, and $\mathrm{O}$ was carried out using a Vario EL III CHNOS Elemental Analyzer (Elementar, Langenselbold, Germany). The $\mathrm{Cu}$ content was determined based on edta titration in the presence of 1-(2-pyridylazo)-2-naphtol as an indicator [32]. Analysis for the studied compound [determined/theoretical (\%)]: C 48.9/49.8; H 6.0/6.1; O 27.1/26.5; Cu 16.9/17.6. The FT-IR spectra were recorded on a Jasco FT/IR 6200 spectrophotometer (JASCO, Easton, MD, USA), in the form of $\mathrm{KBr}$ pellets, in the spectral range $4000-400 \mathrm{~cm}^{-1}$, with resolution $1 \mathrm{~cm}^{-1}$. The thermal decompositions were carried out with a Netzsch STA 449 F1 Jupiter thermoanalyzer (Netzsch-Geratebau GmbH, Selb, Germany) coupled with a Netzsch Aeolos Quadro QMS 403 mass spectrometer (Netzsch-Geratebau $\mathrm{GmbH}$, Selb, Germany). Samples were heated in $\mathrm{Al}_{2} \mathrm{O}_{3}$ crucibles, in the temperature range $35-1000{ }^{\circ} \mathrm{C}$, with the heating rate $10{ }^{\circ} \mathrm{C} / \mathrm{min}$ in synthetic air $\left(80 \% \mathrm{~N}_{2}, 20 \% \mathrm{O}_{2}\right)$.

\section{Results and Discussion}

\subsection{Structural Analysis}

The studied compound tetrakis( $\mu$-tiglato)bis(tiglic acid)dicopper(II) is the first coordination compound of copper with tiglate anion, the structure of which was determined [12]. This is a dinuclear compound, whose two copper cations are bridged by four tiglate anions with syn-syn mode, forming a paddle-wheel structure (Figure 2a) [33]. The coordination sphere of the central atom is completed by monodentate tiglic acid coordinating by carbonyl oxygen. The coordination polyhedron adopts the geometry of a tetragonal pyramid (Figure $2 b, c$ ), in which the equatorial positions are occupied by oxygen atoms of anions and the axial position by carbonyl oxygen of acid. The presence of the inversion center (special position $b$ of $P 2_{1} / c$ space group) in the middle between copper cations makes that the one-half of the compound $\left[\mathrm{Cu}(\mathrm{tig})_{2}(\mathrm{tigH})\right]$ is equivalent to the second one. The bond valence sum of $\mathrm{Cu} 1$ is 1.976 (Table 2) [34-37], and it is close to the formal charge 2+ of copper, which proves that $\mathrm{Cu} \bullet \bullet \mathrm{Cu}$ interaction has a nonbonding character [38].
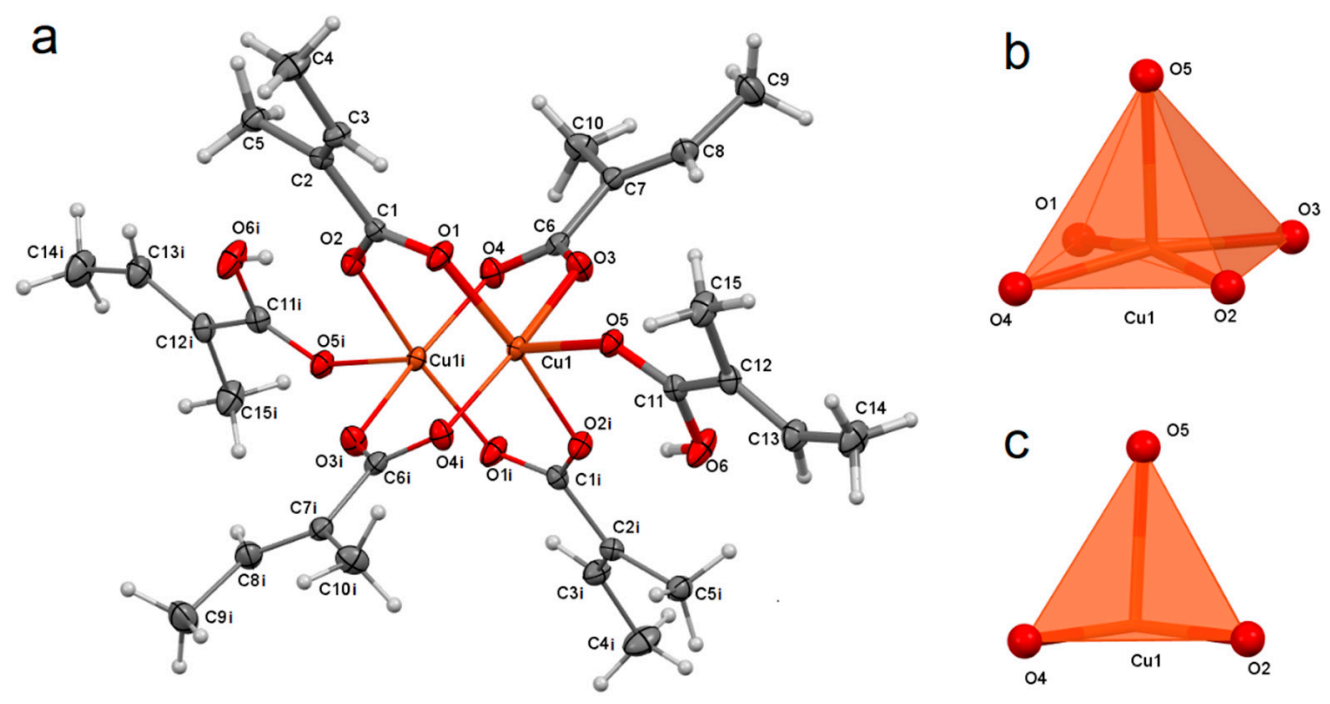

Figure 2. Molecular structure of $\left[\mathrm{Cu}_{2}(\mathrm{tig})_{4}(\mathrm{tigH})_{2}\right]$, with atom numbering scheme, plotted with $50 \%$ probability of displacement ellipsoids of nonhydrogen atoms. Hydrogen atoms are plotted as spheres of arbitrary radii. The symmetry generated atoms are indicated by $\mathrm{i}$ letter [symmetry code: $-\mathrm{x}+1,-\mathrm{y}+1,-\mathrm{z}+1](\mathrm{a})$. Coordination polyhedron of $\left[\mathrm{Cu}_{2}(\mathrm{tig})_{4}(\mathrm{tigH})_{2}\right]$, general view (b), view along tetragonal base (c). 
Table 2. Selected structural data of the studied compound.

\begin{tabular}{|c|c|c|c|c|c|c|}
\hline $\mathrm{i}-\mathrm{j}$ & $\mathrm{d}_{\mathrm{ij}}(\AA)$ & $v_{\mathrm{ij}}$ (v.u.) & $\mathrm{i}-\mathrm{j}-\mathrm{k}$ & $\alpha_{\mathrm{ijk}}\left({ }^{\circ}\right)$ & $\mathrm{i}-\mathrm{j}-\mathrm{k}$ & $\alpha_{\mathrm{ijk}}\left({ }^{\circ}\right)$ \\
\hline $\mathrm{Cu} 1-\mathrm{O} 1$ & $1.9530(10)$ & 0.448 & $\mathrm{O} 1-\mathrm{Cu} 1-\mathrm{O} 2^{\mathrm{i}}$ & $169.39(4)$ & $\mathrm{O} 2^{\mathrm{i}}-\mathrm{Cu} 1-\mathrm{O} 4^{\mathrm{i}}$ & $88.42(4)$ \\
\hline $\mathrm{Cu} 1-\mathrm{O} 2^{\mathrm{i}}$ & $1.9955(10)$ & 0.399 & $\mathrm{O} 1-\mathrm{Cu} 1-\mathrm{O} 3$ & $89.93(5)$ & $\mathrm{O} 2^{\mathrm{i}}-\mathrm{Cu} 1-\mathrm{O} 5$ & $91.76(4)$ \\
\hline $\mathrm{Cu} 1-\mathrm{O} 3$ & $1.9515(10)$ & 0.450 & $\mathrm{O} 1-\mathrm{Cu} 1-\mathrm{O} 4^{\mathrm{i}}$ & $90.37(4)$ & $\mathrm{O} 3-\mathrm{Cu} 1-\mathrm{O} 4^{\mathrm{i}}$ & $169.61(4)$ \\
\hline $\mathrm{Cu} 1-\mathrm{O} 4^{\mathrm{i}}$ & $1.9528(10)$ & 0.448 & $\mathrm{O} 1-\mathrm{Cu} 1-\mathrm{O} 5$ & $98.85(4)$ & $\mathrm{O} 3-\mathrm{Cu} 1-\mathrm{O} 5$ & $94.02(4)$ \\
\hline $\mathrm{Cu} 1-\mathrm{O} 5$ & $2.1991(10)$ & 0.230 & $\mathrm{O} 2^{\mathrm{i}}-\mathrm{Cu} 1-\mathrm{O} 3$ & $89.38(4)$ & $\mathrm{O} 44^{\mathrm{i}}-\mathrm{Cu} 1-\mathrm{O} 5$ & $96.19(4)$ \\
\hline $\mathrm{Cu} 1 \bullet \bullet \mathrm{Cu} 1^{\mathrm{i}}$ & $2.5956(4)$ & - & - & - & - & - \\
\hline $\mathrm{D}-\mathrm{H} \bullet \bullet A$ & \multicolumn{2}{|c|}{$\mathrm{d}(\mathrm{D}-\mathrm{H})(\AA)$} & $\mathrm{d}(\mathrm{H} \bullet \bullet A)(\AA)$ & $\mathrm{d}(\mathrm{D} \bullet \bullet \bullet \mathrm{A})(\AA)$ & $<(\mathrm{DHA})\left(^{\circ}\right)$ & Graph-Set \\
\hline $\mathrm{O} 6-\mathrm{H} 6 \mathrm{O} \bullet \bullet \bullet 2^{\mathrm{i}}$ & \multicolumn{2}{|c|}{0.82} & 1.82 & $2.6345(14)$ & 170.3 & $S(6)$ \\
\hline
\end{tabular}

The bond valences were calculated as $v_{\mathrm{ij}}=\exp \left[\left(R_{i j}-d_{i j}\right) / b\right][34,35]$, where $R_{i j}$ is the bond-valence parameter for $i-j$ bond $\left(R_{\mathrm{Cu}-\mathrm{O}}=1652 \AA\right.$ [36] $)$ and $b$ is the constant equaled $0.37 \AA$ [37]. Symmetry transformations used to generate equivalent atoms: (i) $-\mathrm{x}+1,-\mathrm{y}+1,-\mathrm{z}+1$.

The structural features of the studied compound were compared with 12 known dicopper compounds with the formula $\left[\mathrm{Cu}_{2}(\mathrm{~A})_{4}(\mathrm{HA})_{2}\right]$ (where: $\mathrm{HA}$ is a carboxylic acid and $\mathrm{A}$ is its anion) [12]. It was reported that $\mathrm{Cu} \bullet \bullet \mathrm{Cu}$ distance depends on an axial ligand [39]. More nucleophilic axial ligands lead to a lengthening of dicopper distance as a result of the formation of a stronger $\mathrm{Cu}-\mathrm{L}$ (axial) bond. Taking into account only carboxylic acids as the axial ligands allows estimation of the strength of $\mathrm{Cu}-\mathrm{O}$ (axial) bonds based on their length. The comparison of $\mathrm{Cu} \bullet \bullet \mathrm{Cu}$ distance with $\mathrm{Cu}-\mathrm{O}$ (axial) length for $\left[\mathrm{Cu}_{2}(\mathrm{~A})_{4}(\mathrm{HA})_{2}\right]$ compounds shows no significant relationship (Figure 3a). In the studied compound, both mentioned structural parameters (Table 2) are within standard deviations of the mean values $(2.61 \pm 0.02 \AA$ and $2.17 \pm 0.03 \AA$, respectively) calculated for the group of $\left[\mathrm{Cu}_{2}(\mathrm{~A})_{4}(\mathrm{HA})_{2}\right]$ compounds. The lack of correlation between mentioned parameters means that differences in strength of acids resulting from different substituents bonded to a carboxylic group do not influence the dicopper distance. It can be a consequence of the intramolecular hydrogen bond formed between the hydroxyl group of acid and the oxygen of one bridging anion. The formation of $S(6)$ hydrogen-bonded ring introduces some strains to the structure, which can affect a disruption of the correlation between the above-discussed structural parameters. While the direct influence of h-bond strength on the dicopper distance is not observed (Figure $3 b$ ), there is an inverse relationship between h-bond $\mathrm{O}$ (donor) $\bullet \bullet \mathrm{O}$ (acceptor) distance and the $\mathrm{Cu}-\mathrm{O}$ (axial) bond length (Figure $3 \mathrm{c}$ ). It means that an increase in strength of the intramolecular h-bond causes the weakening of the $\mathrm{Cu}-\mathrm{O}$ (axial) bond. This h-bond in the studied compound is one of the strongest in the $\left[\mathrm{Cu}_{2}(\mathrm{~A})_{4}(\mathrm{HA})_{2}\right]$ group. It is a consequence of coupling between the carboxylate group and the double bond, which increases the nucleophilic character of the h-bond acceptor. Moreover, the involvement of one equatorial oxygen in the h-bond leads to significant lengthening of its coordination bond in comparison to the rest of the three equatorial bonds (Table 2). This phenomenon is observed for the whole $\left[\mathrm{Cu}_{2}(\mathrm{~A})_{4}(\mathrm{HA})_{2}\right]$ group (Figure $3 \mathrm{~d}$ ) and the mean difference between the longest equatorial bond and the rest equatorial bonds is $0.03 \AA$. Only one exception is the compound of triphenylactetic acid (CSD refcode: ROLZUN [16]), in which the equatorial coordination bond involved in the h-bond has the second-shortest length (white stars in Figure 3d). This is a consequence of a large steric hindrance of ligands. Because four bridging triphenylacetate anions cannot rich the most favorable position in the inner coordination sphere, they form strongly asymmetrical bridges. 

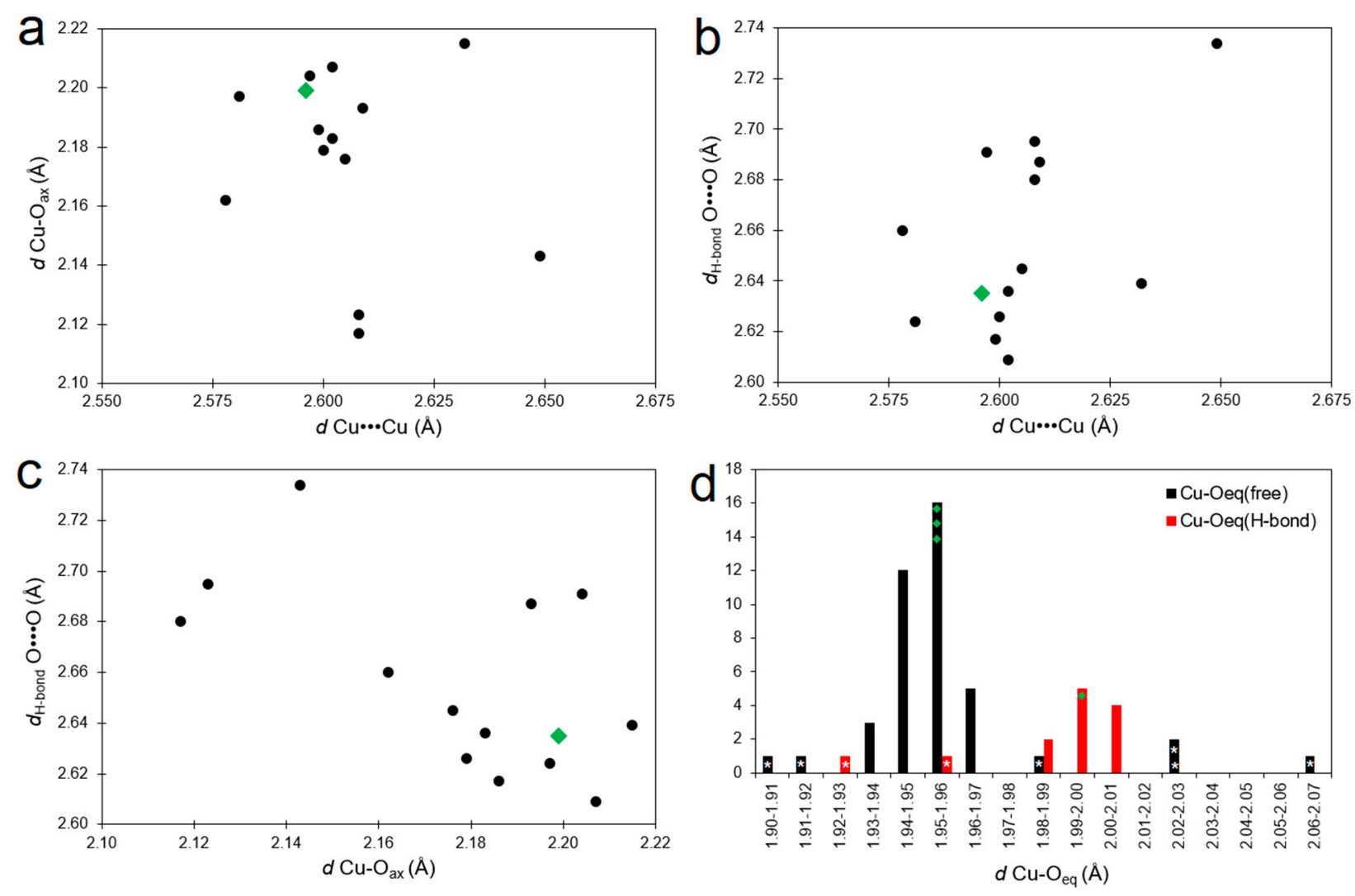

Figure 3. Scatterplots $(\mathbf{a}-\mathbf{c})$ and histogram (d) presenting relationships between selected structural parameters in $\left[\mathrm{Cu}_{2}(\mathrm{~A})_{4}(\mathrm{HA})_{2}\right]$ compound group (CSD refcodes of included structures: ACACCV10, FAKRUE, GUGROP, KALQET, KIJKUJ, KUBHOE01, LATXEL, MODCOY, QIXGOU, ROZLUN, SUGHIL01, WEVWEZ). Green color indicates data of $\left[\mathrm{Cu}_{2}(\mathrm{tig})_{4}(\mathrm{tigH})_{2}\right]$. White stars indicate data of $\left[\mathrm{Cu}_{2} \text { (triphenylacetate }\right)_{4}$ (triphenylacetic acid $\left.)_{2}\right]$ (CSD refcode: ROLZUN). For compounds, in which both copper cations are symmetry-dependent, one data set is presented. Two data sets are included only for ROZLUN, whose copper cations are not equivalent.

The crystal structure of the studied compound is stabilized by dispersive interactions and weak hydrogen bonds. The above discussed $\mathrm{O}-\mathrm{H} \bullet \bullet \bullet \mathrm{O}$ hydrogen bond is an intramolecular interaction; thus it does not influence molecular packing. The analysis of the Hirshfeld surface and the 2D fingerprint plots revealed that the greatest contribution in intermolecular contacts has dispersive $\mathrm{H} \bullet \bullet \bullet \mathrm{H}$ interactions (Figure 4), which are formed between hydrogens of two methyl groups or methyl and methine groups. The next in turn of these are the weak hydrogen bonds $\mathrm{C}-\mathrm{H} \bullet \bullet \bullet \mathrm{O}$ and $\mathrm{C}-\mathrm{H} \bullet \bullet \bullet \mathrm{C}$. Enrichment ratios for such three main interaction types are very close or higher than 1 (Figure 4), which indicates that they are favorable for the crystal net [40]. The ER value for C-H $\bullet \bullet \bullet \mathrm{O}$ is the largest, which means that these interactions play a slightly more important role in supramolecular assembling in comparison to the rest.

\subsection{IR Spectroscopy Analysis}

The spectrum of the studied compound contains absorption bands in the regions, which are characteristic of tiglic acid and its anion (Figure 5). For pure acid, the $v(C=O)$ vibrations are identified as the strong bands at 1678 and $1639 \mathrm{~cm}^{-1}$. In its spectrum, there are also $v(\mathrm{OH})$ and $\delta(\mathrm{OH})$ modes in the ranges $3300-2500 \mathrm{~cm}^{-1}$ and $1440-1380 \mathrm{~cm}^{-1}$, respectively. Additionally, bands of the stretching $\mathrm{CH}$ vibrations exist in the region $3300-2500 \mathrm{~cm}^{-1}$. Characteristic absorption modes for $v(\mathrm{C}-\mathrm{O})$ appear at 1348 and $1293 \mathrm{~cm}^{-1}$. In the region $900-600 \mathrm{~cm}^{-1}$, bands of $\gamma(\mathrm{CH})$ are observed. The spectrum of $\left[\mathrm{Cu}_{2}(\mathrm{tig})_{4}(\mathrm{tigH})_{2}\right]$ is poorer than that of free acid. In comparison to tiglic acid, all bands are shifted to higher and lower frequencies as a result of the coordination process. The bands at $1677 \mathrm{~cm}^{-1}$, 
$1399 \mathrm{~cm}^{-1}, 1372 \mathrm{~cm}^{-1}$, and $1269 \mathrm{~cm}^{-1}$ are assigned respectively to $v(\mathrm{C}=\mathrm{O}), \delta(\mathrm{OH})$ and $v(\mathrm{C}-\mathrm{O})$, and they are the evidence of the presence of coordinated acid molecules in the copper compound. In its spectrum, there are also bands characteristic of tiglate anions. The most important are two bands originating from stretching vibrations of the carboxylate group: $v_{\text {as }}(\mathrm{COO})$ at $1591 \mathrm{~cm}^{-1}$ and $v_{\mathrm{s}}(\mathrm{COO})$ at $1496 \mathrm{~cm}^{-1}$. It proves that $\mathrm{COO}$ groups are bonded to copper(II) ions. In the spectrum of the copper compound, the absorption bands of $\gamma(\mathrm{CH})$ exist at $824 \mathrm{~cm}^{-1}, 749 \mathrm{~cm}^{-1}$, and $673 \mathrm{~cm}^{-1}$.
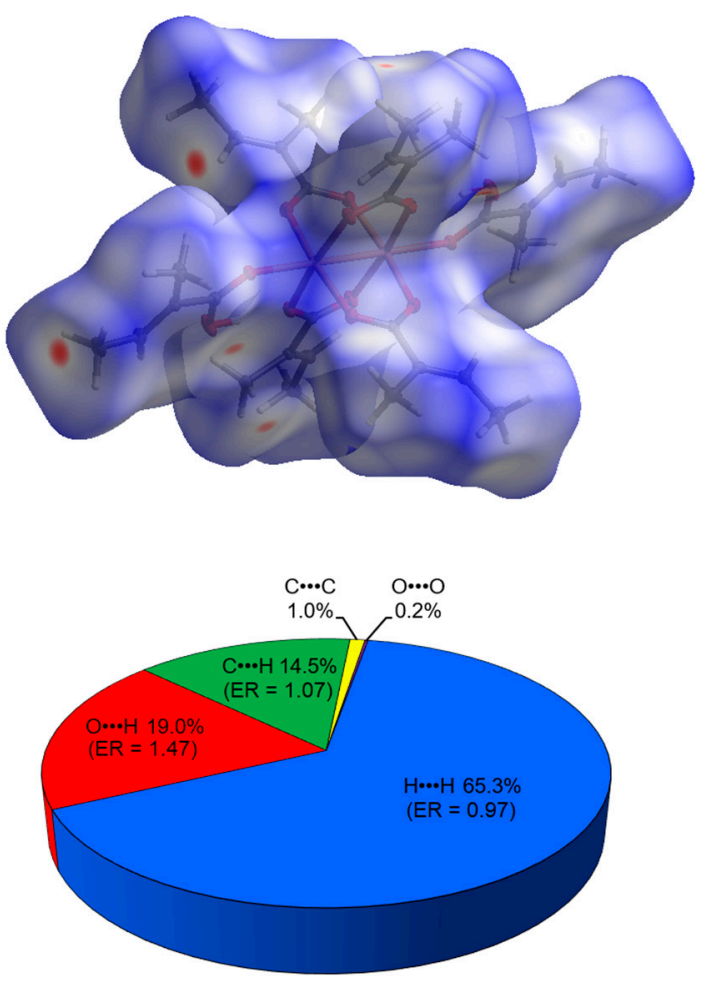
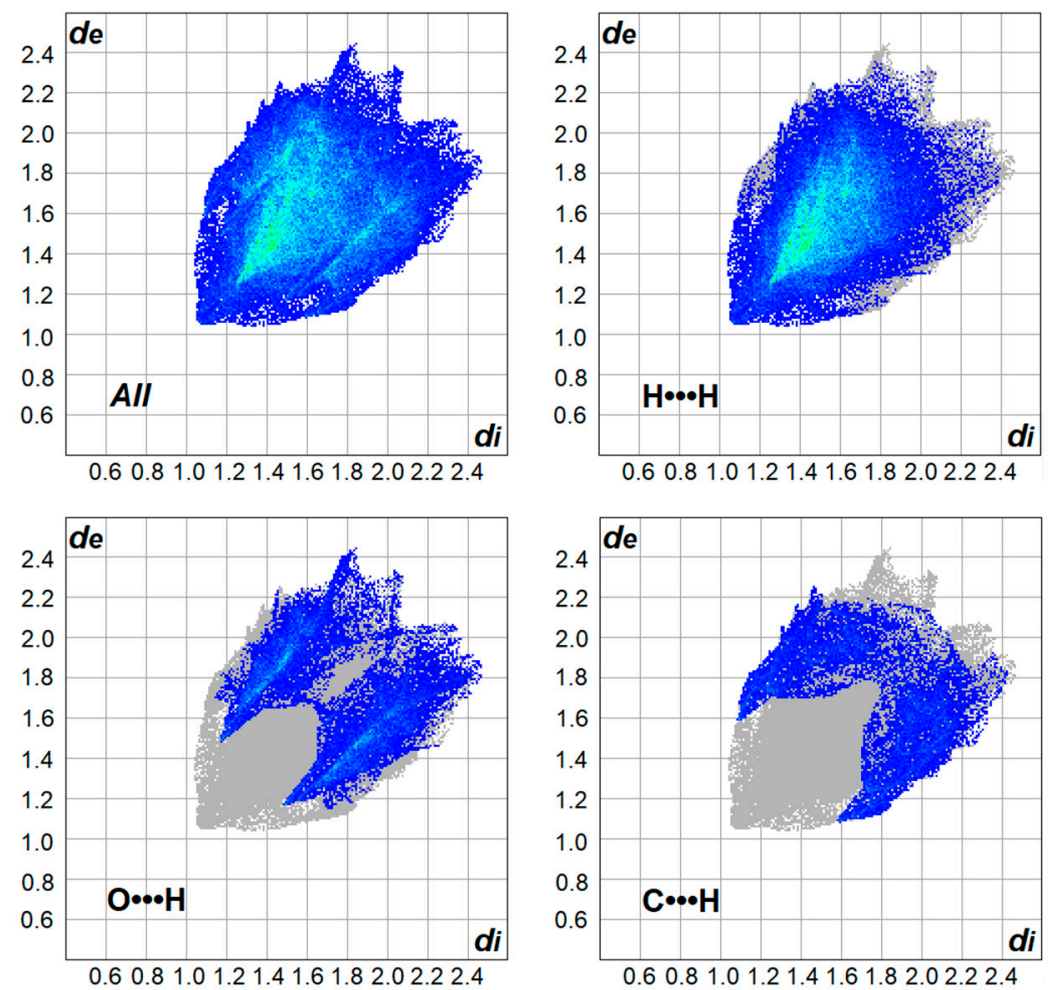

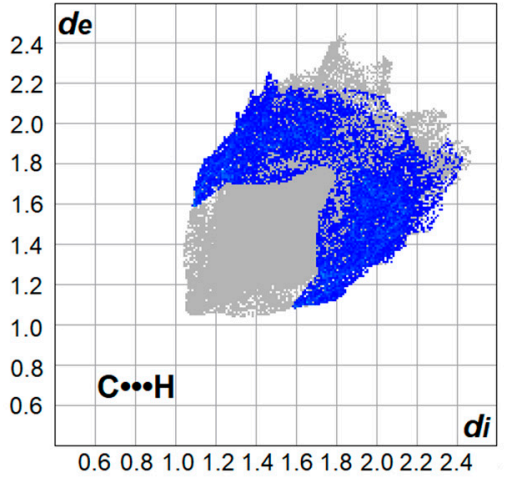

Figure 4. Hirshfeld surface (plotted over $\mathrm{d}_{\text {norm }}$ ), 2D fingerprint plots, and percentage distribution of the intermolecular contacts in the studied compound.

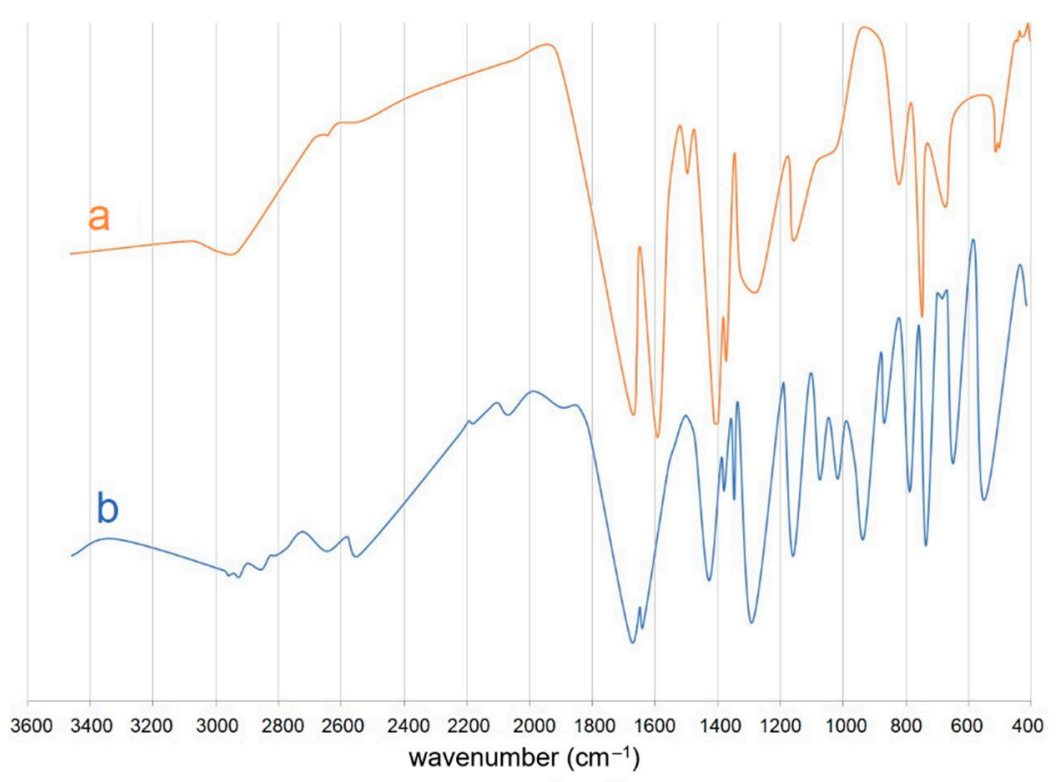

Figure 5. FT-IR spectra of $\left[\mathrm{Cu}_{2}(\mathrm{tig})_{4}(\mathrm{tigH})_{2}\right](\mathbf{a})$ and tiglic acid (b). 


\subsection{Thermal Analysis}

The studied coordination compound is stable up to $120{ }^{\circ} \mathrm{C}$ (Figure 6a). The first step of decomposition takes place in the temperature range $120-200^{\circ} \mathrm{C}$ and is associated with a loss of two molecules of tiglic acid (mass loss 26.7\%, calculated 27.6\%). This is an endothermic process with the maximum on the DTA curve at $175{ }^{\circ} \mathrm{C}$. For comparison, thermal decomposition of free tiglic acid starts at $50^{\circ} \mathrm{C}$ (Figure $6 \mathrm{~b}$ ), and this is an exothermic process (two peaks at 90 and $170{ }^{\circ} \mathrm{C}$ on the DTA curve). It proves that the formation of coordination bonds makes tiglic acid more thermally stable and changes the mechanism of decomposition (exothermic for free acid and endothermic for coordinating acid). The second decomposition step of $\left[\mathrm{Cu}_{2}(\mathrm{tig})_{4}(\mathrm{tigH})_{2}\right]$ is the disintegration of tiglate anions (mass loss $51.4 \%$, calculated $50.3 \%$ ). It occurs directly after the decomposition of tiglic acids and ends at $415{ }^{\circ} \mathrm{C}$. It is an exothermic process composed of several substages (peaks at 240, 260,340 , and $410^{\circ} \mathrm{C}$ on DTA curve). The mass residue is $21.9 \%$, which indicates that the final solid product is $\mathrm{CuO}$ (calculated 22.1\%).
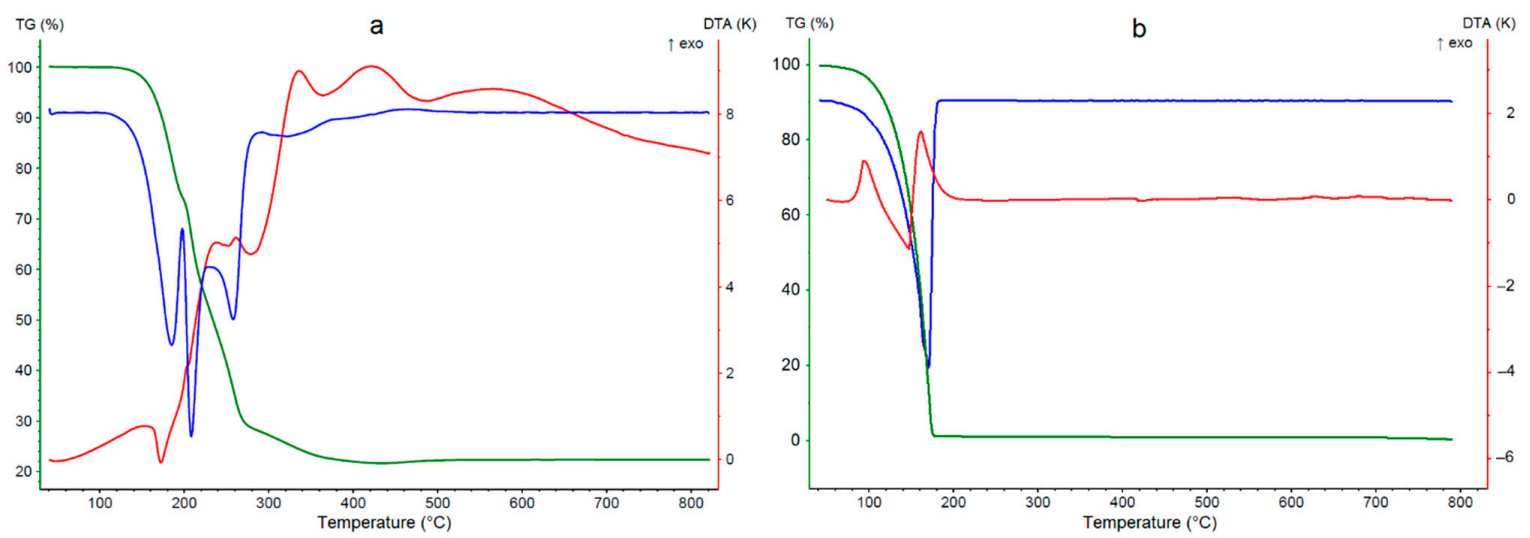

Figure 6. TG (green), DTG (blue), and DTA (red) curves for $\left[\mathrm{Cu}_{2}(\mathrm{tig})_{4}(\mathrm{tigH})_{2}\right](\mathbf{a})$ and tyglic acid (b).

Mass spectra registered during the thermal analysis of $\left[\mathrm{Cu}_{2}(\mathrm{tig})_{4}(\mathrm{tigH})_{2}\right]$ revealed the volatile products formed during decomposition (Figure 7). Major maxima for ion currents were observed at temperatures $180^{\circ} \mathrm{C}$ (the first decomposition step) and $250{ }^{\circ} \mathrm{C}$ (the second decomposition step). The signals for $\mathrm{m} / \mathrm{z}=12,17,18,44,45,46$ correspond to $\mathrm{C}^{+}, \mathrm{OH}^{+}$, $\mathrm{H}_{2} \mathrm{O}^{+}, \mathrm{CO}_{2}{ }^{+}$, and they are connected with the combustion of organic ligands. Other signals $(\mathrm{m} / \mathrm{z}=15,26,27,29,34,39,40,41,42,53,54,55,72$, and 83$)$ are the result of fragmentation processes of ligands.
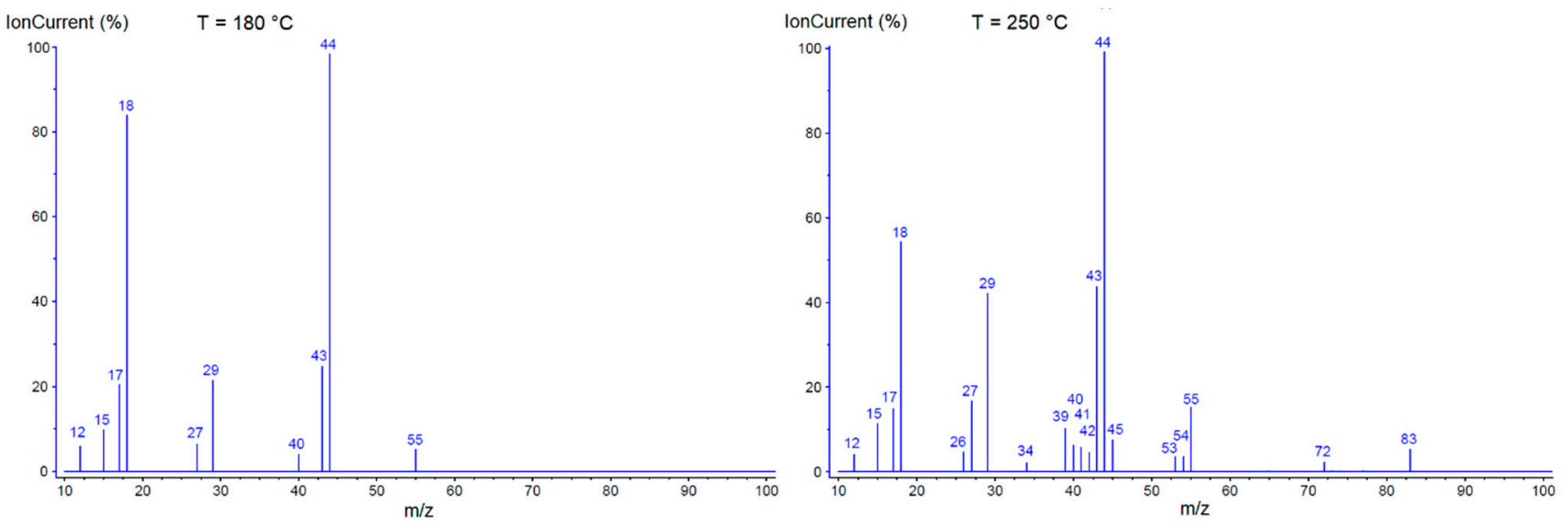

Figure 7. Mass spectra of volatile products from the thermal decomposition of $\left[\mathrm{Cu}_{2}(\mathrm{tig})_{4}(\mathrm{tigH})_{2}\right]$ registered at $180{ }^{\circ} \mathrm{C}$ and $250{ }^{\circ} \mathrm{C}$. The elaboration of the mass spectra involved subtracting the background spectrum and application of an automatic software correction for the carrier gas. 


\subsection{SQUID Magnetization Analysis}

Figure 8 shows the temperature dependence of the molar magnetic susceptibility $\chi_{\exp }(T)$ of $3.4 \pm 0.2 \mathrm{mg}$ sample of $\left[\mathrm{Cu}_{2}(\mathrm{tig})_{4}(\mathrm{tigH})_{2}\right]$ measured at $H=0.6 \mathrm{~T}$ and presented as $\chi_{\exp } \times T$ plot (black circles). A slow roll down of $\chi_{\exp } \times T$ on lowering $T$ confirms that the $\mathrm{Cu}(\mathrm{II})-\mathrm{Cu}$ (II) coupling is antiferromagnetic, which means that the low temperature ground state of this dimer is a nonmagnetic singlet. A relatively strong magnetic response at high $T$, above $60 \%$ of the expected signal of two noninteracting $\mathrm{Cu}$ (II) spins, indicates that the energy separating the ground singlet state from the excited triplet states, $-2 \mathrm{~J}$, is of the order of thermal energy at room temperature, $k_{\mathrm{B}} T \cong 25 \mathrm{meV} \cong 200 \mathrm{~cm}^{-1}$; $k_{\mathrm{B}}$ is the Boltzmann constant. This allows a substantial population of the lowest, the magnetically active $m_{\mathrm{S}}=-1$ triplet state and so such a substantial magnetic response above some $150 \mathrm{~K}$. The magnitude of the antiferromagnetic exchange coupling $-2 J$ was estimated by fitting to the experimental results the model Bleaney-Bowers formulae describing the $T$-dependence of the magnetic susceptibility of two interacting $S=1 / 2$ spins defined by the Hamiltonian $\mathrm{H}=-2 J S_{1} S_{2}$ [41]. The Curie law contribution was also added to give an account of a paramagnetic-like increase of $\chi_{\exp }$ at very low temperatures due to some structural defects [42] and a $T$-independent parameter describing the diamagnetism of the host structure, $\chi_{\text {dia }}$. In the performed modeling $-2 J, \chi_{\text {dia }}$, and two molar concentrations of $\mathrm{Cu}$ dimers and paramagnetic defects, $n_{\text {dimer }}$ and $n_{\text {para }}$, respectively, were the fitting parameters. The resulting fit to $\chi_{\exp }(T)$ is denoted in Figure 8 by the red solid line. It has been obtained for $-2 J=292.0(3) \mathrm{cm}^{-1}, n_{\text {para }}=0.008$, and $n_{\text {dimer }}=1.09$. The magnitude of $-2 \mathrm{~J}$ established for the studied compound matches almost perfectly the exchange integral found in copper acetate $\left[\mathrm{Cu}_{2}\left(\mathrm{CH}_{3} \mathrm{COO}\right)_{4}\left(\mathrm{H}_{2} \mathrm{O}\right)_{2}\right]: 286 \mathrm{~cm}^{-1}$ [14], which is a consequence of similar electronic properties of tiglate and acetate anions ( $\mathrm{pKa}=4.96$ [43] and 4.76 [44], respectively). If analogous dicopper compound $\left[\mathrm{Cu}_{2}\left(\mathrm{CCl}_{3} \mathrm{COO}\right)_{4}\left(\mathrm{CCl}_{3} \mathrm{COOH}\right)_{2}\right]$ is composed of a stronger carboxylic acid (pKa for trichloroacetic acid is $0.66[44]$ ), $-2 J$ value decreases to $240 \mathrm{~cm}^{-1}$ [45]. Given an experimental uncertainty of the absolute mass of the powder used to prepare the specimen (about $6 \%$ ), $n_{\text {dimer }}$ was found to be very close to the expected value of unity. Since $n_{\text {para }}$ is close to zero the magnetic studies confirm a very high structural and chemical constitution of the synthesized material.

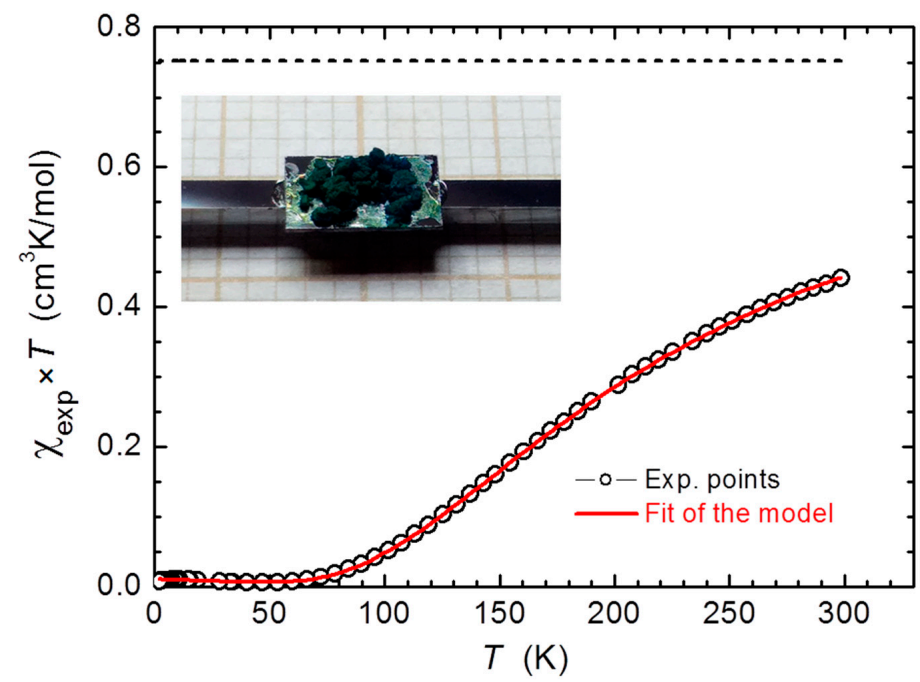

Figure 8. Experimental magnetic susceptibility $\chi_{\exp } \times T$ of $\left[\mathrm{Cu}_{2}(\mathrm{tig})_{4}(\mathrm{tigH})_{2}\right]$ plot vs. temperature $T$. Experimental points are marked by black circles and the results of the modelling including $\mathrm{T}$ dependent response of a $\mathrm{Cu}(\mathrm{II})-\mathrm{Cu}(\mathrm{II})$ dimer (mid-to-high $\mathrm{T}$ range), a Curie paramagnetic-like contribution (very low temperatures) and T-independent diamagnetism of the host are depicted as the red solid line. The black dashed line denotes the Curie constant calculated for two noninteracting $S=\frac{1}{2}$ spins. The inset: $\left[\mathrm{Cu}_{2}(\mathrm{tig})_{4}(\mathrm{tigH})_{2}\right]$ powder specimen attached to the rectangular Si support plate and mounted onto a Si holder. 


\section{Conclusions}

The reaction between copper(II) carbonate hydroxide and tiglic acid led to obtaining the dinuclear copper compound of the paddle-wheel structure composed of four syn-syn bridging tiglate anions and two monodentate tiglic acid molecules. The structural data supported by the bond valence theory proves that interaction between copper cations in $\left[\mathrm{Cu}_{2}(\mathrm{tig})_{4}(\mathrm{tigH})_{2}\right]$ has a nonbonding character. The $\mathrm{OH}$ group of tiglic acid forms an intramolecular hydrogen bond with carboxylate oxygen of one tiglate anion. The involvement of one tiglate oxygen in h-bond leads to significant lengthening of its coordination bond with copper in comparison to the rest of the tiglate oxygens. The supramolecular structure of the studied compound is stabilized by $\mathrm{H} \bullet \bullet \bullet \mathrm{H}$ dispersive interactions and weak $\mathrm{C}-\mathrm{H} \bullet \bullet \bullet \mathrm{O}$ and $\mathrm{C}-\mathrm{H} \bullet \bullet \bullet \mathrm{C}$ hydrogen bonds. The FT-IR spectrum contains bands corresponding to both tiglic acid and tiglate anion. The vibration modes of carboxylic and carboxylate groups are well distinguishable. Thermal analysis showed that tiglic acid molecules decompose before tiglate anions. The final product of decomposition is $\mathrm{CuO}$. The magnetic measurements of the studied material indicate its very high structural and chemical quality and yield the antiferromagnetic configuration of $\mathrm{Cu}$ (II) ions, thus opening wide prospects of utilization in various fields as, e.g., biosensors, capacitors, transistors, or in data storage systems [46-49].

Supplementary Materials: The supplementary materials are available online at https:/ /www.mdpi. com/article/10.3390/ma14092148/s1.

Author Contributions: Conceptualization, M.Ś. and A.C.; investigation, M.Ś., S.L., K.G., and M.S.; formal analysis, K.G. and M.S.; writing—original draft preparation, M.Ś., S.L., and A.C.; writingreview and editing, M.Ś., M.S., and A.C.; visualization, M.Ś. and A.C.; supervision, M.Ś. and A.C. All authors have read and agreed to the published version of the manuscript.

Funding: The crystallographic studies were performed thanks to funds allocated by the Ministry of Science and Higher Education (Poland) to the Institute of General and Ecological Chemistry, Lodz University of Technology (SPUB/SP/457471/2020).

Institutional Review Board Statement: Not applicable.

Informed Consent Statement: Not applicable.

Data Availability Statement: The data presented in this study are available on request from the corresponding author.

Acknowledgments: The authors would like to dedicate this work to the memory of Rafał Kruszyński, who was the initiator of this research. Rafał Kruszyński passed away in September 2020. The authors thank Jacek Szczytko and Marcin Witkowski from the Institute of Experimental Physics, Faculty of Physics, University of Warsaw for inspiring discussions on the magnetic state of the material.

Conflicts of Interest: The authors declare no conflict of interest.

\section{References}

1. Attygalle, A.B.; Wu, X.; Ruzicka, J.; Rao, S.; Garcia, S.; Herath, K.; Meinwald, J.; Maddison, D.R.; Will, K.W. Defensive Chemicals Of Two Species Of Trachypachus Motschulski. J. Chem. Ecol. 2004, 30, 577-588. [CrossRef] [PubMed]

2. Davidson, B.S.; Eisner, T.; Witz, B.; Meinwald, J. Defensive Secretion of the Carabid Beetle. J. Chem. Ecol. 1989, $15,1689-1697$. [CrossRef] [PubMed]

3. Larios, A.; Garcia, H.S.; Oliart, R.M.; Valerio-Alfaro, G. Synthesis of flavor and fragrance esters using Candida antarctica lipase. Appl. Microbiol. Biotechnol. 2004, 65, 373-376. [CrossRef] [PubMed]

4. Buckles, R.E.; Mock, G.V.; Locatelli, L. Tiglic and angelic acid. Chem. Rev. 1955, 55, 659-677. [CrossRef]

5. Wang, H.-Q.; Ma, S.-G.; Lin, M.-B.; Hou, Q.; Ma, M.; Yu, S.-S. Hydroxylated Ethacrylic and Tiglic Acid Derivatives from the Stems and Branches of Enkianthus chinensis and Their Potential Antiinflammatory Activities. J. Nat. Prod. 2020, 83, 2867-2876. [CrossRef]

6. Alesiani, D.; Canini, A.; D'Abrosca, B.; DellaGreca, M.; Fiorentino, A.; Mastellone, C.; Monaco, P.; Pacifico, S. Antioxidant and antiproliferative activities of phytochemicals from Quince (Cydonia vulgaris) peels. Food Chem. 2010, 118, 199-207. [CrossRef]

7. Attygalle, A.B.; Wu, X.; Will, K.W. Biosynthesis of Tiglic, Ethacrylic, and 2-Methylbutyric Acids in a Carabid Beetle, Pterostichus (Hypherpes) californicus. J. Chem. Ecol. 2007, 33, 963-970. [CrossRef] 
8. Stromnova, T.A.; Monakhov, K.Y.; Campora, J.; Palma, P.; Carmona, E.; Alvarez, E. Synthesis and solution behavior of the trinuclear palladium(II) unsaturated carboxylate complexes triangle- $\mathrm{Pd} 3\left[\mu-\mathrm{O} 2 \mathrm{CC}\left(\mathrm{R}^{\prime}\right)=\mathrm{CHMe}\right]_{6}\left(\mathrm{R}^{\prime}=\mathrm{Me}, \mathrm{H}\right)$ : X-ray structure of palladium(II) tiglate $\left(\mathrm{R}^{\prime}=\mathrm{Me}\right)$. Inorg. Chim. Acta 2007, 360, 4111-4116. [CrossRef]

9. Lu, W.; Wu, B.; Zheng, X. Terbium and holmium trans-2,3-dimethylacrylic acid complexes with 1,10-phenanthroline. J. Chem. Crystallogr. 2000, 30, 777-782. [CrossRef]

10. Edwards, D.A.; Mahon, M.F.; Molloy, K.C.; Ogrodnik, V. Aerosol-assisted chemical vapour deposition of silver films from adducts of functionalised silver carboxylates. J. Mater. Chem. 2003, 13, 563-570. [CrossRef]

11. Clegg, W.; Cressey, J.T.; Harbron, D.R.; Straughan, B.P. Polymeric and mixed carboxylate compounds: Crystal structures of [Zn(tiglate)2]x and [Zn2(tiglate)3(crotonate)]x. J. Chem. Crystallogr. 1994, 24, 211-217. [CrossRef]

12. Groom, C.R.; Bruno, I.J.; Lightfoot, M.P.; Ward, S.C. Cambridge Structural Database, CSD v 5.39, August 2018. Acta Crystallogr. Sect. B Struct. Sci. Cryst. Eng. Mater. 2016, 72, 171-179. [CrossRef]

13. van Niekerk, J.N.; Schoening, F.R.L. A New Type of Copper Complex as found in the Crystal Structure of Cupric Acetate, $\mathrm{Cu}_{2}\left(\mathrm{CH}_{3} \mathrm{COO}\right)_{4} \cdot 2 \mathrm{H}_{2} \mathrm{O}$. Acta Crystallogr. 1953, 6, 227-232. [CrossRef]

14. Figgis, B.N.; Martin, R.L. Magnetic studies with copper(II) salts. Part I. Anomalous paramagnetism and $\delta$-bonding in anhydrous and hydrated copper(II) acetates. J. Chem. Soc. 1956, 3837-3846. [CrossRef]

15. Martin, R.L.; Waterman, H. Magnetic studies with copper(II) salts. Part II. Anomalous paramagnetism and $\delta$-bonding in anhydrous and hydrated copper(II)n-alkanoates. J. Chem. Soc. 1957, 2545-2551. [CrossRef]

16. Fomina, I.; Dobrokhotova, Z.; Aleksandrov, G.; Bogomyakov, A.; Fedin, M.; Dolganov, A.; Magdesieva, T.; Novotortsev, V.; Eremenko, I. Influence of the nature of organic components in dinuclear copper(II) pivalates on the composition of thermal decomposition products. Polyhedron 2010, 29, 1734-1746. [CrossRef]

17. Cheprakova, E.M.; Verbitskiy, E.V.; Kiskin, M.A.; Aleksandrov, G.G.; Slepukhin, P.A.; Sidorov, A.A.; Starichenko, D.V.; Shvachko, Y.N.; Eremenko, I.L.; Rusinov, G.L.; et al. Synthesis and characterization of new complexes derived from 4-thienyl substituted pyrimidines. Polyhedron 2015, 100, 89-99. [CrossRef]

18. Nikolaevskii, S.A.; Kiskin, M.A.; Starikov, A.G.; Efimov, N.N.; Bogomyakov, A.S.; Minin, V.V.; Ugolkova, E.A.; Nikitin, O.M.; Magdasieva, T.V.; Sidorov, A.A.; et al. Atmospheric Oxygen Influence on the Chemical Transformations of 4,5-Dimethyl-1,2Phenylenediamine in the Reactions with Copper(II) Pivalate. Russ. J. Coord. Chem. 2019, 45, 279-287. [CrossRef]

19. Lutsenko, I.A.; Baravikov, D.E.; Kiskin, M.A.; Nelyubina, Y.V.; Primakov, P.V.; Bekker, O.B.; Khoroshilov, A.V.; Sidorov, A.A.; Eremenko, I.L. Bioisostere Modifications of $\mathrm{Cu}^{2+}$ and $\mathrm{Zn}^{2+}$ with Pyromucic Acid Anions and N-Donors: Synthesis, Structures, Thermal Properties, and Biological Activity. Russ. J. Coord. Chem. 2020, 46, 411-419. [CrossRef]

20. Polunin, R.A.; Burkovskaya, N.P.; Kolotilov, S.V.; Kiskin, M.A.; Bogomyakov, A.S.; Sotnik, S.A.; Eremenko, I.L. Synthesis, structures, sorption and magnetic properties of coordination polymers based on $3 \mathrm{~d}$ metal pivalates and polydentate pyridine-type ligands. Russ. Chem. Bull. 2014, 63, 252-266. [CrossRef]

21. Campbell, G.C.; Haw, J.F. Determination of magnetic and structural properties in solids containing antiferromagnetically coupled metal centers using NMR methods. Magneto-structural correlations in anhydrous copper(II) n-butyrate. Inorg. Chem. 1988, 27, 3706-3709. [CrossRef]

22. Campbell, G.C.; Reibenspies, J.H.; Haw, J.F. Solid-state NMR studies of magneto-structural correlations in anhydrous copper(II) carboxylates. Inorg. Chem. 1991, 30, 171-176. [CrossRef]

23. Steward, O.W.; Johnston, B.S.; Chang, S.-C.; Harada, A.; Ohba, S.; Tokii, T.; Kato, M. Structural and Magnetic Studies of Dimeric Copper(II) 2,2-diphenylopropanoato and Triphenylacetato Complexes with Oxygen-Donor Ligands. The Cage Geometry of Dimeric $\alpha$-Phenyl Substituted Copper(II) Carboxylates. Bull. Chem. Soc. Jpn. 1996, 69, 3123-3137. [CrossRef]

24. Melnik, M. Study of the relation between the structural data and magnetic interactions in oxo-bridged binuclear copper(II) compounds. Coord. Chemi. Rev. 1982, 42, 259-293. [CrossRef]

25. Kawata, T.; Uekusa, H.; Ohba, S. Magneto-Structural Correlation in Dimeric Copper(II) Benzoates. Acta Crystallogr. Sect. B Struct. Sci. 1992, 48, 253-261. [CrossRef]

26. Sheldrick, G.M. SHELXT-Integrated space-group and crystal-structure determination. Acta Crystallogr. Sect. A Found. Adv. 2015, 71, 3-8. [CrossRef]

27. Sheldrick, G.M. Crystal structure refinement with SHELXL. Acta Crystallogr. Sect. C. Struct. Chem. 2015, 71, 3-8. [CrossRef] [PubMed]

28. Macrae, C.F.; Bruno, I.J.; Chisholm, J.A.; Edgington, P.R.; McCabe, P.; Pidcock, E.; Rodriguez-Monge, L.; Taylor, R.; van de Streek, J.; Wood, P.A. Mercury CSD 2.0-New Features for the Visualization and Investigation of Crystal Structures. J. Appl. Cryst. 2008, 41, 466-470. [CrossRef]

29. CrystalExplorer17; University of Western Australia: Perth, Australia, 2019.

30. Tun Nur Iskandar, N.A.J.; Guan-Yeow, Y.; Maeta, N.; Ito, M.M.; Nakamura, Y.; Gas, K.; Sawicki, M. Anisotropic and magnetic properties in non-metal and non-radical organic aggregates of tri-substituted phenyl derivatives. New J. Chem. 2020, 44, $210-217$. [CrossRef]

31. Sawicki, M.; Stefanowicz, W.; Ney, A. Sensitive SQUID magnetometry for studying nanomagnetism. Semicond. Sci. Technol. 2011, 26, 064006. [CrossRef]

32. Welcher, F.J. Analityczne Zastosowanie Kwasu Wersenowego (eng. The Analytical Uses of Etylenediamineteraacetic Acid); WNT: Warsaw, Poland, 1963; pp. 241-242. 
33. Pasynskii, A.A.; Shapovalov, S.S.; Gordienko, A.V.; Razuvaev, D.I.; Skabitsky, I.V.; Aleksandrov, G.G.; Dobrohotova, Z.W.; Bogomyakov, A.S. Dimeric "paddle-wheel" cymantrenylcarboxylates of copper (II). Inorg. Chim. Acta 2012, 384, 18-22. [CrossRef]

34. Zachariasen, W.H. Bond lengths in oxygen and halogen compounds of d and f elements. J. Less-Common Met. 1978, 62, 1-7. [CrossRef]

35. Brown, I.D. Influence of Chemical and Spatial Constraints on the Structures of Inorganic Compounds. Acta Crystallogr. Sect. B Struct. Sci. 1997, 53, 381-393. [CrossRef]

36. Shields, P.G.; Raithby, P.R.; Allen, F.H.; Motherwell, W.D.S. The assignment and validation of metal oxidation states in the Cambridge Structural Database. Acta Crystallogr. Sect. B Struct. Sci. 2000, 56, 455-465. [CrossRef]

37. Brown, I.D. Chemical and steric constraints in inorganic solids. Acta Crystallogr. Sect. B Struct. Sci. 1992, 48, 553-572. [CrossRef]

38. Valach, F.; Tokarcik, M.; Maris, T.; Watkin, D.J.; Prout, C.K. Bond-valence approach to the copper-copper and copper-oxygen bonding in binuclear copper(II) complexes: Structure of tetrakis(2-fluorobenzoato-O,O0)-bis(2-fluorobenzoate-O) dicopper(II). Z. Kristallogr. 2000, 215, 56-60. [CrossRef]

39. Rao, V.M.; Sathyanarayana, D.N.; Manohar, H. X-ray crystal structures of some adducts of dimeric copper(II) acetate. Nature of the copper-copper interaction. J. Chem. Soc. Dalton Trans. 1983, 10, 2167-2173. [CrossRef]

40. Jelsch, C.; Esjmont, K.; Huder, L. The enrichment ratio of atomic contacts in crystals, an indicator derived from the Hirshfeld surface analysis. IUCrJ 2014, 1, 119-128. [CrossRef] [PubMed]

41. Bleaney, B.; Bowers, K.D. Anomalous paramagnetism of copper acetate. Proc. R. Soc. Lond. Ser. A 1952, 214, 451-465.

42. Gardias, A.; Kaszyński, P.; Obijalska, E.; Trzybiński, D.; Domagała, S.; Woźniak, K.; Szczytko, J. Magnetostructural Investigation of Orthogonal 1-Aryl-3-Phenyl-1,4-Dihydrobenzo[e][1,2,4]triazin-4-yl Derivatives. Chem. Eur. J. 2018, 24, 1317. [CrossRef]

43. Kortum, G.; Vogel, W.; Andrussow, K. Dissociation Constants of Organic Acids in Aqueous Solution; Butterworths: London, UK, 1961.

44. Lide, D.R. (Ed.) CRC Handbook of Chemistry and Physics, 86th ed.; Taylor and Francis: Boca Raton, FL, USA, 2006.

45. Dell'Amico, D.B.; Alessio, R.; Calderazzo, F.; Della Pina, F.; Englert, U.; Pampaloni, G.; Passarelli, V. Synproportionation reactions between copper(II) trihalogenoacetates $\mathrm{Cu}\left(\mathrm{CX}_{3} \mathrm{CO}_{2}\right)_{2}, \mathrm{X}=\mathrm{F}, \mathrm{Cl}$ or $\mathrm{Br}$, and copper in the presence of carbon monoxide. J. Chem. Soc. Dalton Trans. 2000, 13, 2067-2075. [CrossRef]

46. Zhou, Z.; Zhang, Y.; Guo, M.; Huang, K.; Xu, W. Ultrasensitive magnetic DNAzyme-copper nanoclusters fluorescent biosensor with triple amplification for the visual detection of E. coli O157:H7. Biosens. Bioelectron. 2020, 167, 112475. [CrossRef] [PubMed]

47. Kawrani, S.; Boulos, M.; Cornu, D.; Bechelany, M. From Synthesis to Applications: Copper Calcium Titanate (CCTO) and its Magnetic and Photocatalytic Properties. ChemistryOpen 2019, 8, 922-950. [CrossRef] [PubMed]

48. Magadur, G.; Lauret, J.-S.; Charron, G.; Bouanis, F.; Norman, E.; Huc, V.; Cojocaru, C.-S.; Gómez-Coca, S.; Ruiz, E.; Mallah, T. Charge transfer and tunable ambipolar effect induced by assembly of $\mathrm{Cu}(\mathrm{II})$ binuclear complexes on carbon nanotube field effect transistor devices. J. Am. Chem. Soc. 2012, 134, 7896-7901. [CrossRef] [PubMed]

49. Tiwari, A. Magnetic materials and devices: Research and applications. JOM 2011, 63, 24. [CrossRef] 